DOI 10.15290/cnisk.2020.02.09.11

PIOTR RODZIK

https://orcid.org/0000-0002-3126-1938

Ośrodek Przetwarzania Informacji - Państwowy Instytut Badawczy

\title{
W jakim stopniu obecnie kobiety awansują naukowo?
}

\section{Streszczenie}

Artykuł poświęcony jest trendom w obszarze nadanych w kraju tytułów naukowych profesora i tytułów profesora w zakresie sztuki oraz stopni naukowych doktora i doktora habilitowanego, a także stopni w zakresie sztuki. Podczas prezentacji wyników uwzględniono podział osób uzyskujących stopnie i tytuły według płci, pokazano, jak zmienia się liczba osób, którym nadano stopnie i tytuły w kolejnych latach, oraz określono, jak zmienia się liczba nadanych stopni i tytułów w zależności od wieku osób uzyskujących stopień lub tytuł. Pokazano również zmianę charakteru awansu naukowego kobiet w badanym okresie oraz ich udział w kierowaniu finansowanymi przez NCN projektami badawczymi. Analizy oparto na danych jednostkowych oraz (częściowo) na dostępnych danych statystycznych obejmujących 20 ostatnich lat (1999-2018).

Słowa kluczowe: stopnie naukowe, tytuły naukowe, płeć, awans naukowy, projekty badawcze

\section{HOW ARE WOMEN SCIENTIFICALLY ADVANCING NOWADAYS?}

\begin{abstract}
The article is devoted to trends observed in the numbers of scientific titles and scientific degrees granted in Poland for women and men. It is shown how the numbers of scientific degrees and titles granted in consecutive years were changed due to age of person and how the number of
\end{abstract}


granted research grants depends on gender of a project leader. The change of character of scientific advancement of women in examined period also was shown. Analysis is made basing on unit data and fragmentally on public statistical data collected during last 20 years (1999-2018).

Keywords: scientific degrees, academic titles, gender, scientific advancement, research grant

\section{Wstęp}

W kwietniu 2009 r. pojawił się artykuł Kto zdobywa stopnie $i$ tytuly naukowe - troche statystyki1, a w 2016 artykuly Nadane stopnie i tytuły naukowe - czy coś się zmieniło?2 i Awans naukowy kobiet - czy coś się zmieniło? ${ }^{3}$. Sprawdzimy, czy przedstawione tam trendy dotyczące stopni i tytułów naukowych nadawanych kobietom nadal sa aktualne.

Trendy w zakresie nadawanych stopni doktora w Polsce niemal w $100 \%$ pokrywają się $z$ trendami w USA $^{4}$ pomimo znacznie większej liczby stopni doktora nadawanych w USA (wykres 7). Inaczej jest w Unii Europejskiej (UE-28), gdzie średni procent kobiet otrzymujacych stopień doktora powoli dochodzi do $48 \%$ (publikacje She Figures ${ }^{5}$ ), ale trzeba tu zaznaczyć, że chodzi o wartość średnia, a rozbieżności pomiędzy poszczególnymi krajami (które moga wynikać zarówno $z$ charakteru gromadzonych przez poszczególne kraje danych, jak i przyjętej metodologii ich przeliczania) wynosza dla roku 2016 od $40 \%$ do prawie $70 \%$ udziału kobiet $\mathrm{w}$ nadawanych stopniach doktora. Sprawozdawane różnice sa więc ogromne i uśrednienie ich dla znacznej części państw znacznie obniża procent kobiet, którym nadano stopień doktora. Nieco inaczej jest w krajach azjatyckich: np. w Japonii, w 2001 r., udział kobiet wynosił

\footnotetext{
1 Piotr Rodzik, „Kto zdobywa stopnie i tytuły naukowe - trochę statystyki”, Sprawy Nauki, nr 4, 2009, 16-20.

2 Piotr Rodzik, „Nadane stopnie i tytuły naukowe - czy coś się zmieniło?”, Nauka i Szkolnictwo Wyższe, nr 2 (48), 2016, 139-74.

3 Piotr Rodzik, „Awans naukowy kobiet - czy coś się zmieniło?”, Nauka, nr 4, 2016, 93-110.

4 "Number of doctoral degrees earned in the United States from 1949/50 to 2028/29, by gender", Statista, [online] [dostęp: 07.12.2019]. Dostępny w World Wide Web: https://www. statista.com/statistics / 185167/number-of-doctoral-degrees-by-gender-since-1950/.

5 "She Figures 2012. Gender Equality in Science", (Brussels: European Commission, 2013); "She Figures 2015", (Luxembourg : Publications Office of the European Union, 2016); "She Figures 2018", (Luxembourg : Publications Office of the European Union, 2019).
} 
tylko $21 \%$, a w $2011-27,65 \%^{6}$, podobnie jest na Taiwanie i w Korei (tu nieco lepiej). Na tej podstawie można stwierdzić, że pozycja kobiet w krajach Azji zmienia się (rośnie) - ale niezbyt szybko.

\section{Przyjęta metodologia}

Przyjęta metodologie oraz stosowana klasyfikację opisano we wcześniejszych publikacjach Nadane stopnie i tytuły naukowe - czy coś się zmieniło? i Awans naukowy kobiet - czy coś się zmieniło?

Ponieważ w obliczeniach statystycznych jedna $z$ najważniejszych rzeczy jest wybór źródła danych, wybrano odpowiednie źródła danych dla każdego zakresu danych. Najlepiej widać to po danych przedstawianych przez UE w cytowanych już zestawieniach She Figures, gdzie prezentowane wyniki sa oparte na danych przekazywanych przez korespondentów statystycznych $z$ poszczególnych państw na podstawie danych $z$ lokalnych systemów - w efekcie sprawozdane dane nie muszą być porównywalne.

Dla nadanych tytułów naukowych profesora zdecydowano, że jako dane w tym zakresie wykorzystano następujące źródła:

- dla lat 1999-2005 dane pochodzące z prowadzonej przez Ośrodek Przetwarzania Informacji - Państwowy Instytut Badawczy (OPI PIB) Bazy Wiedzy o Nauce Polskiej (BWNP) ${ }^{7}$,

- dla lat 2006-2010 tytuły nadane przez Prezydenta RP Lecha Kaczyńskiego,

- dla lat 2010-2014 tytuły nadane przez Prezydenta RP Bronisława Komorowskiego,

- a dla lat 2015-2018 prowadzoną przez OPI PIB bazę POL-on ${ }^{8}$

W ten sposób dane $z$ lat 2006-2018 pochodza $z$ oficjalnego źró$\mathrm{d} ł a$ - zostały zamieszczone na oficjalnej stronie internetowej prezydenta lub wprowadzone do bazy POL-on na podstawie informacji otrzymanych

\footnotetext{
6 Tsai Li-Ling, Peng Yen-Wen, "Statistics of Women in Science and Technology Education: Data from Taiwan, Japan and South Korea” [online] [dostęp: 12.03.2020]. Dostępny w World Wide Web: https://slideplayer.com/slide/7401984/.

7 Było to jedyne dostępne dla tego okresu źródło danych - w tych latach POL-on jeszcze nie istniał, a dane statystyczne pochodzace $z$ kancelarii Prezydenta RP nie były publikowane na stronie internetowej prezydenta.

8 Dla tytułów nadawanych w latach 2015-2018 na stronie Prezydenta RP podawana jest data wręczenia nominacji, a nie data przyznania tytułu. Na tej podstawie wykonano wszystkie przedstawione tam zestawienia statystyczne.
} 
z Centralnej Komisji do spraw Stopni i Tytułów, a pozostałe dane (lata 1999-2005) zostały wprowadzone przez operatorów OPI PIB do bazy BWNP najpierw na podstawie informacji o nadanych tytułach naukowych zamieszczone $\mathrm{w}$ prasie, a potem na podstawie zawiadomień otrzymywanych $z$ kancelarii prezydenta.

W zestawieniach nie uwzględniono roku 2019, ponieważ:

1. część tytułów została nadana zgodnie $z$ klasyfikacją dziedzin określona w 2011 r. ${ }^{9}$, a część zgodnie $z$ klasyfikacją obowiązująca od 2018 r. ${ }^{10}$, 2. nie wszystkie dane za rok 2019 zostały wprowadzone do bazy POL-on.

Dla stopni naukowych (doktora i doktora habilitowanego) przyjęto dwa źródła: w latach 1999-2011 BWNP, a w latach 2011-2018 POL-on, który stał się źródłem oficjalnych zestawień publikowanych na stronie Ministra Nauki i Szkolnictwa Wyższego.

Do oceny środków przyznanych na realizację projektów badawczych wykorzystano bazę OSF (Obsługa Strumieni Finansowania - baza prowadzona również przez OPI PIB) w zakresie projektów finansowanych przez Narodowe Centrum Nauki (NCN) i Ministerstwo Nauki i Szkolnictwa Wyższego (MNiSW), a do zestawienia płci kierowników projektów w badaniach posłużył serwis internetowy NCN.

\section{Nadane stopnie i tytuły}

Udział kobiet w nauce cały czas rośnie w tym zakresie (wykres 1). W ciagu ostatnich 20 lat wzrósł prawie o 20\% - o ile w roku 1999 tylko niewiele powyżej 20\% kobiet otrzymywało tytuł profesora, o tyle w 2018 r. było to już prawie $40 \%$.

Niepokojacy jest natomiast fakt, że ogólna liczba nadanych tytułów, w ciagu ostatnich pięciu lat (2014-2018), wykazuje bardzo silna tendencję spadkowa (wykres 2) - w odróżnieniu od tendencji wzrostowej obserwowanej w latach 2006-2014. W latach 2006-2014 (9 lat) liczba

\footnotetext{
9 Rozporządzenie w sprawie obszarów wiedzy, dziedzin nauki i sztuki oraz dyscyplin naukowych i artystycznych, Dz.U. z 2011 r., poz. 1065.

10 Rozporządzenie w sprawie dziedzin nauki i dyscyplin naukowych oraz dyscyplin artystycznych, Dz.U. z 2018 r., poz. 1818.

W nowej klasyfikacji część dziedzin stało się dyscyplinami (np. nauki biologiczne), dlatego dane dotyczące tytułów nadanych w 2019 r. (i w latach późniejszych) nie mogą być porównane $z$ danymi $z$ lat 1999-2018.
} 
nadanych tytułów naukowych wzrosła prawie 2,5-krotnie, podczas gdy w latach 2014-2017 (4 lata) z m ala a ponad 3-krotnie.

Wykres 1. Procentowy udział nadanych w poszczególnych latach tytułów w zależności od płci osoby, której tytuł został nadany

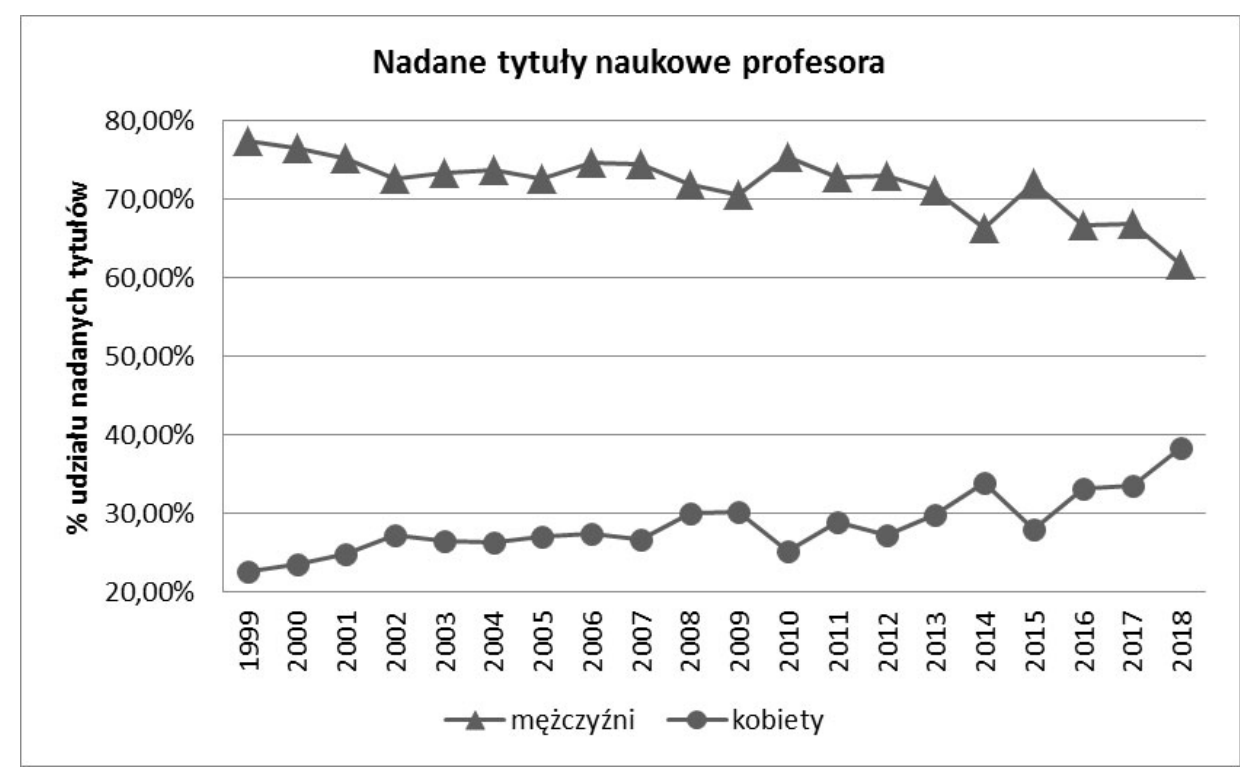

Źródło: opracowanie własne. 
Wykres 2. Liczba nadanych w poszczególnych latach tytułów

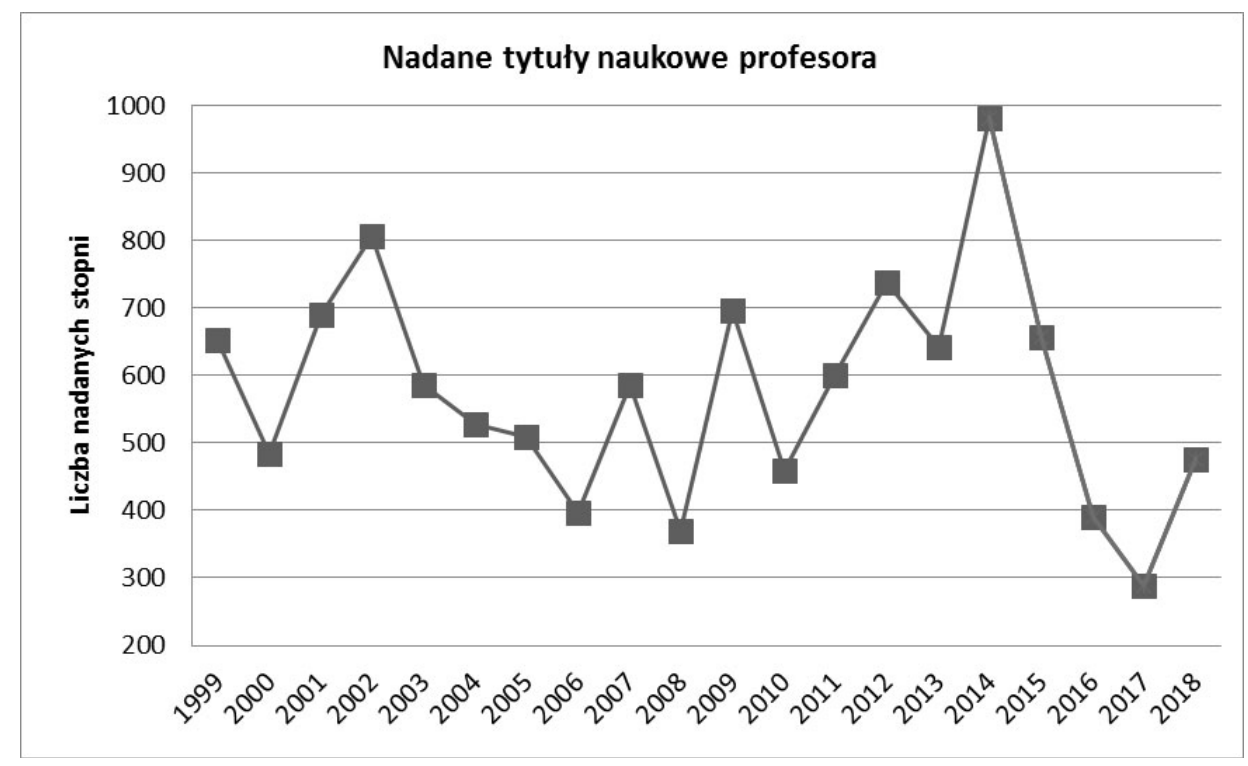

Źródło: opracowanie własne.

Trzeba oczywiście wziąć pod uwagę to, że obserwuje się cykliczną zmianę trendów w nadawaniu tytułów, ale korekta obserwowana w latach 2013-2018 jest wyjątkowo silna - sprowadziła ich liczbę do poziomu najniższego od 20 lat (poniżej 300 tytułów nadanych w 2017 r.).

Jeżeli popatrzymy na wiek, w jakim kobiety otrzymuja tytuł profesora, to na szczęście zanika efekt, który obserwuje się (wykres 3) dla lat 2005-2016 polegający na tym, że mianowanie obejmuje więcej kobiet o dekadę starszych (55-64 lat) niż młodszych (45-54 lat). Od roku 2017 widać już przewagę tytułów naukowych przyznanych kobietom młodszym (45-54 lata), przy czym dla roku 2018 liczba nadanych tytułów naukowych kobietom $z$ tej grupy jest już o około $10 \%$ większa niż dla kobiet w wieku 55-64 lat. Ten sam efekt obserwuje się wśród mężczyzn (wykres 4), ale przewaga osób płci męskiej w wieku 55-65 lat nad mężczyznami w wieku 45-54 lat, którym nadano tytuł profesora, jest w tym przypadku znacznie mniejsza i sięga około 10-15\% (w przypadku kobiet wyniosła ona $20-30 \%)$. 
Wykres 3. Udział procentowy w liczbie nadanych stopni doktora w zależności od wieku, w jakim uzyskiwano stopień - kobiety

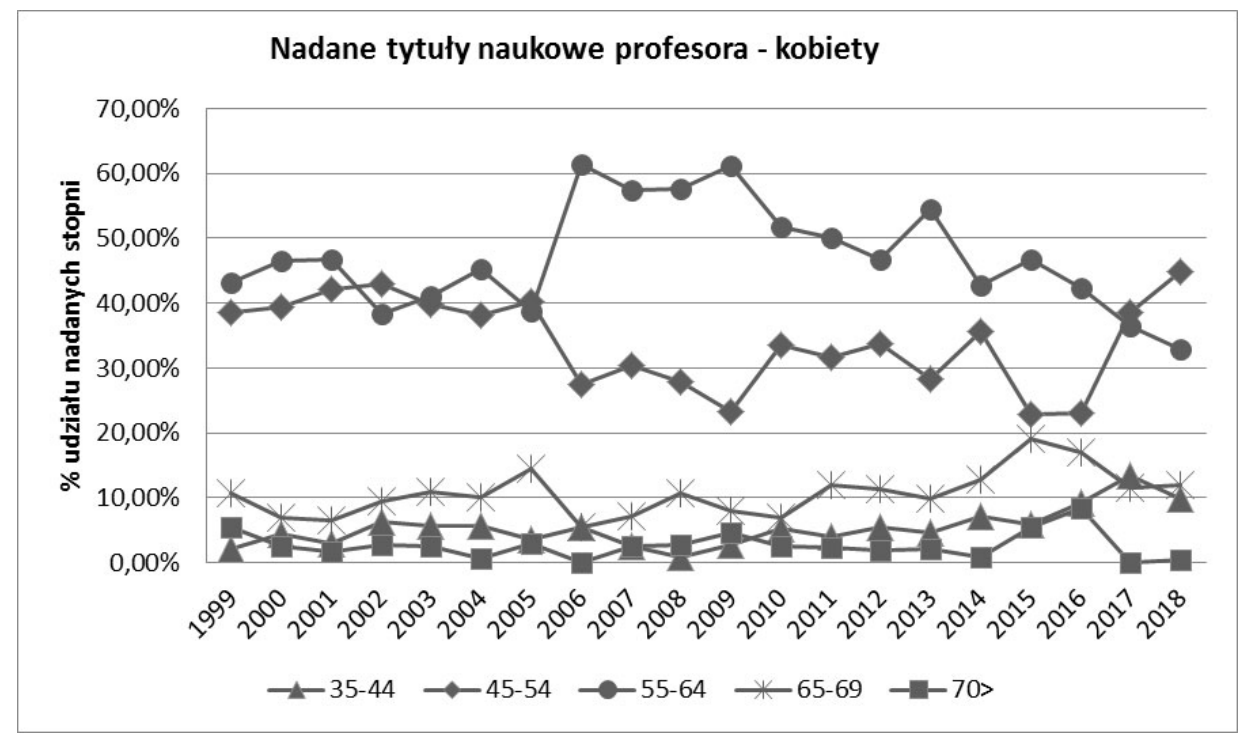

Źródło: opracowanie własne.

Fakt nadawania tytułu osobom starszym był „bardzo mało motywujacy" dla osób zajmujaccych się nauka - jak pokazano wcześniej (Awans naukowy kobiet - czy coś się zmieniło?) - uzyskanie stopnia doktora habilitowanego następowało o około 10 lat wcześniej, a nadanie tytułu profesora o około 10 lat później, co mogło wydłużyć nawet o dwie dekady okres pomiędzy uzyskaniem stopnia doktora habilitowanego i tytułu naukowego profesora przez dana osobę.

Cieszy natomiast fakt istnienia wyraźnego trendu wzrostowego dla tytułów naukowych nadanych kobietom najmłodszym (w wieku 35-44 lat) - o ile w latach 1999-2001 było to 3-4\%, o tyle w latach 2016-2018 było to już 10-12\% wszystkich nadanych kobietom tytułów naukowych. W przypadku mężczyzn wspomniany trend nie jest tak wyraźny i wzrost udziału nadawanych w tym zakresie tytułów wynosi tylko 2-3\%. 
Wykres 4. Udział procentowy w liczbie nadanych stopni doktora w zależności od wieku, w jakim uzyskiwano stopień - mężczyźni

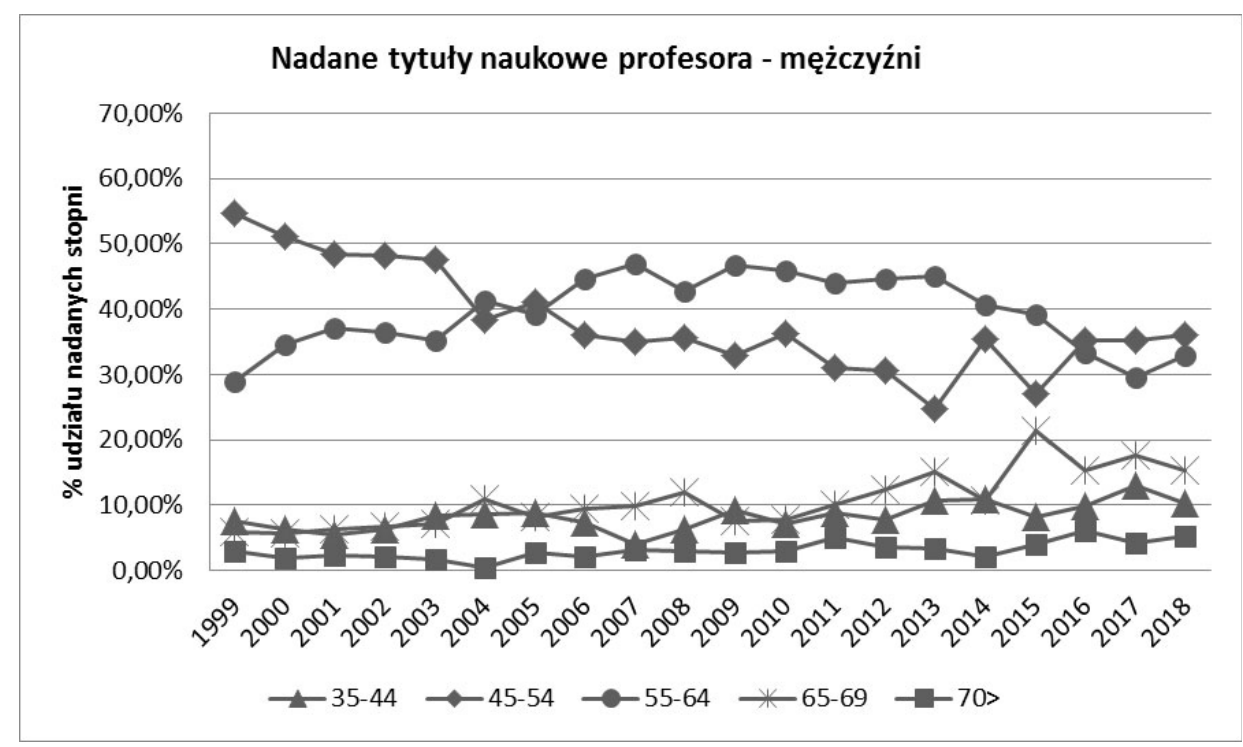

Źródło: opracowanie własne.

Wykres 5. Procentowy udział uzyskanych w poszczególnych latach stopni doktora habilitowanego w zależności od płci osoby

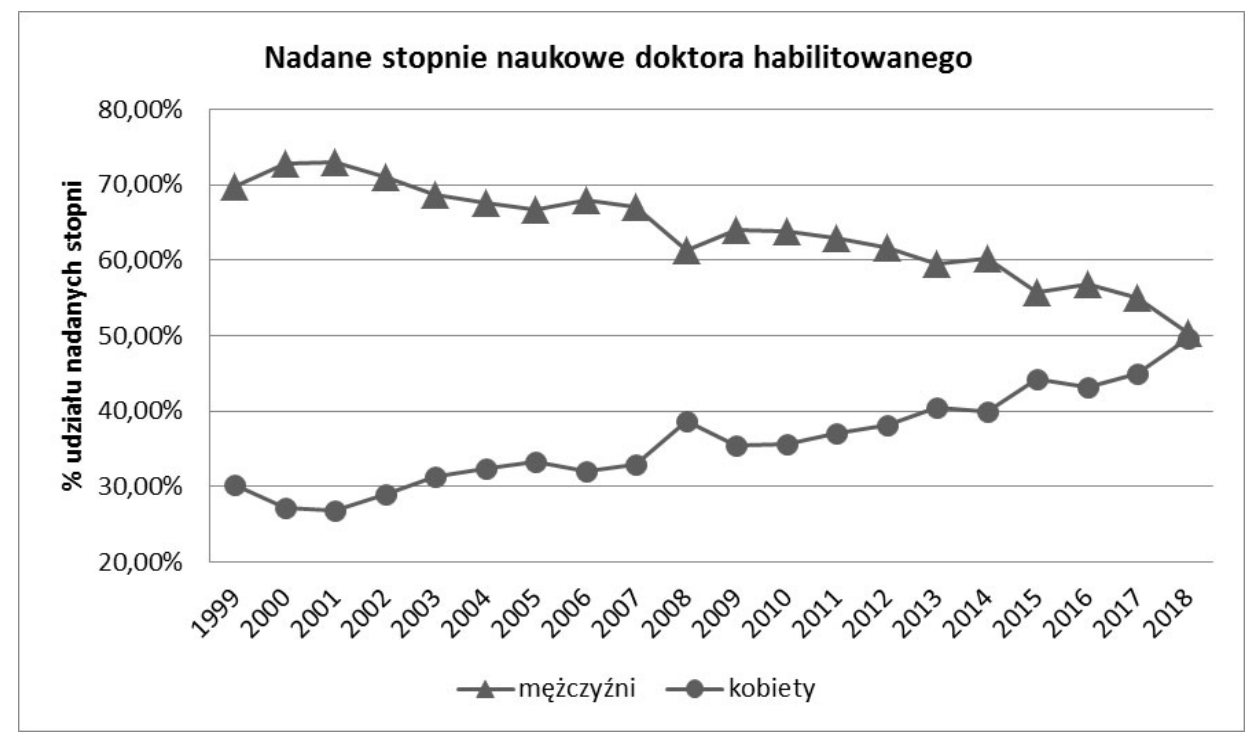

Źródło: opracowanie własne. 
W podobny sposób jak liczba przyznanych kobietom tytułów naukowych profesora wzrasta udział kobiet w liczbie uzyskanych stopni naukowych doktora habilitowanego (wykres 5). O ile w latach 2000-2002 uzyskiwały zaledwie niecałe 30\% stopni doktora habilitowanego, o tyle w roku 2018 liczba uzyskanych przez kobiet stopni doktora habilitowanego praktycznie zrównała się $z$ liczba tych stopni uzyskanych przez mężczyzn - czyli udział stopni uzyskanych przez kobiety sięgnął $50 \%$.

Inaczej niż liczba nadanych tytułów liczba uzyskanych stopni doktora habilitowanego nie została ograniczona do poziomu najniższego od 20 lat (wykres 6). Początkowo mniej więcej stała, następnie gwałtownie wzrosła (najprawdopodobniej efekt zapisów ustawowych ${ }^{11}$ ograniczających czas pomiędzy uzyskiwaniem kolejnych stopni naukowych) i po korekcie (która nastapiła w roku 2015), w latach 2015-2018, znowu mniej więcej ustabilizowała się, ale tym razem na poziomie znacznie wyższym - średnio około 1800 stopni rocznie w porównaniu do poziomu 900-1000 w latach 1999-2010. Wspomniany efekt wynika najprawdopodobniej z obowiazujących przepisów, przy czym „braki zostały nadrobione”. Jak widać, liczba osób, które pozostają w nauce (czyli uzyskały stopień doktora habilitowanego), jest praktycznie stała i wynosi obecnie około 1800 nowych osób rocznie.

11 Ustawa z dnia 27 lipca 2005 r. Prawo o szkolnictwie wyższym, Dz. U. z 2005 r., poz. 1365, z późn. zm. Ustawa z dnia 30 kwietnia 2010 r. o Polskiej Akademii Nauk, Dz. U. z 2010 r., poz. 619. 
Wykres 6. Liczba nadanych w poszczególnych latach stopni doktora habilitowanego

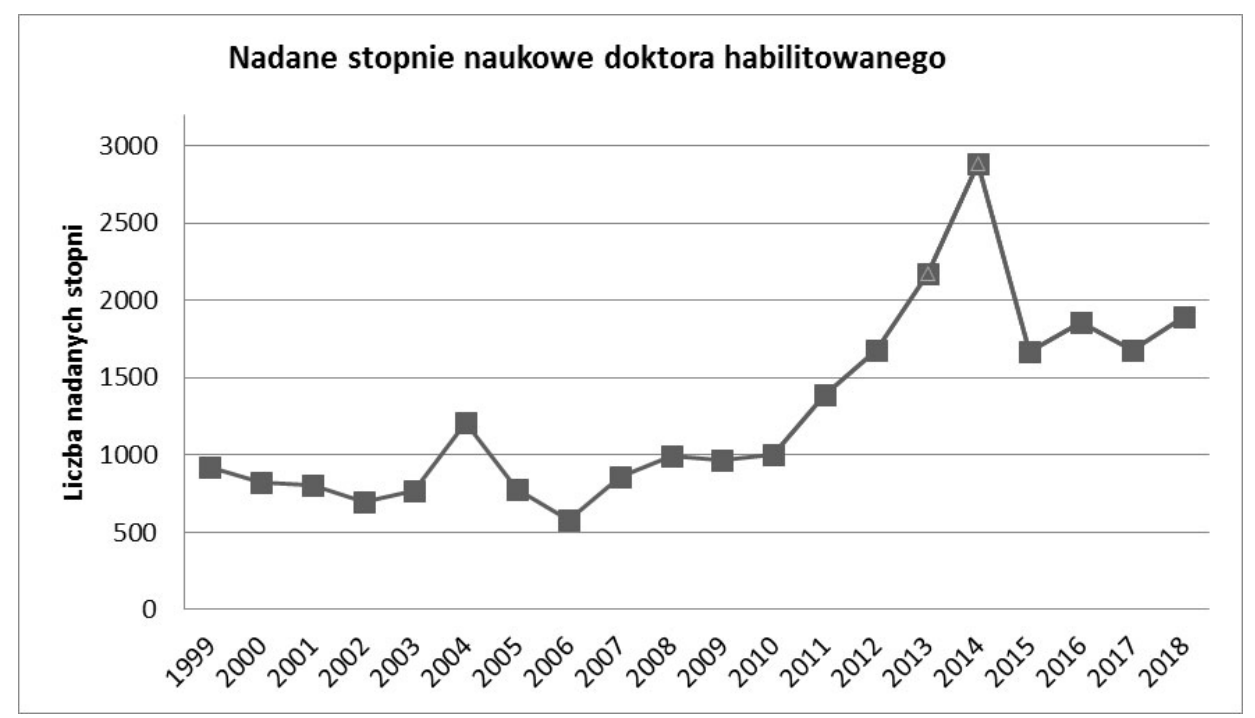

Źródło: opracowanie własne.

Bardzo wyraźnie „efekt płci” widać w uzyskiwaniu przez naukowców stopnia doktora. Od lat więcej kobiet niż mężczyzn uzyskiwało ten stopień (od 2009 r.), ale od pewnego czasu udział kobiet wśród osób, które uzyskały stopień naukowy doktora, przestał wzrastać, a wcześniej dynamika zmian nie była tak wielka jak w przypadku stopnia doktora habilitowanego (to samo zjawisko obserwuje się w USA - wykres 7). 
Wykres 7. Procentowy udział uzyskanych w poszczególnych latach stopni doktora habilitowanego w zależności od płci osoby

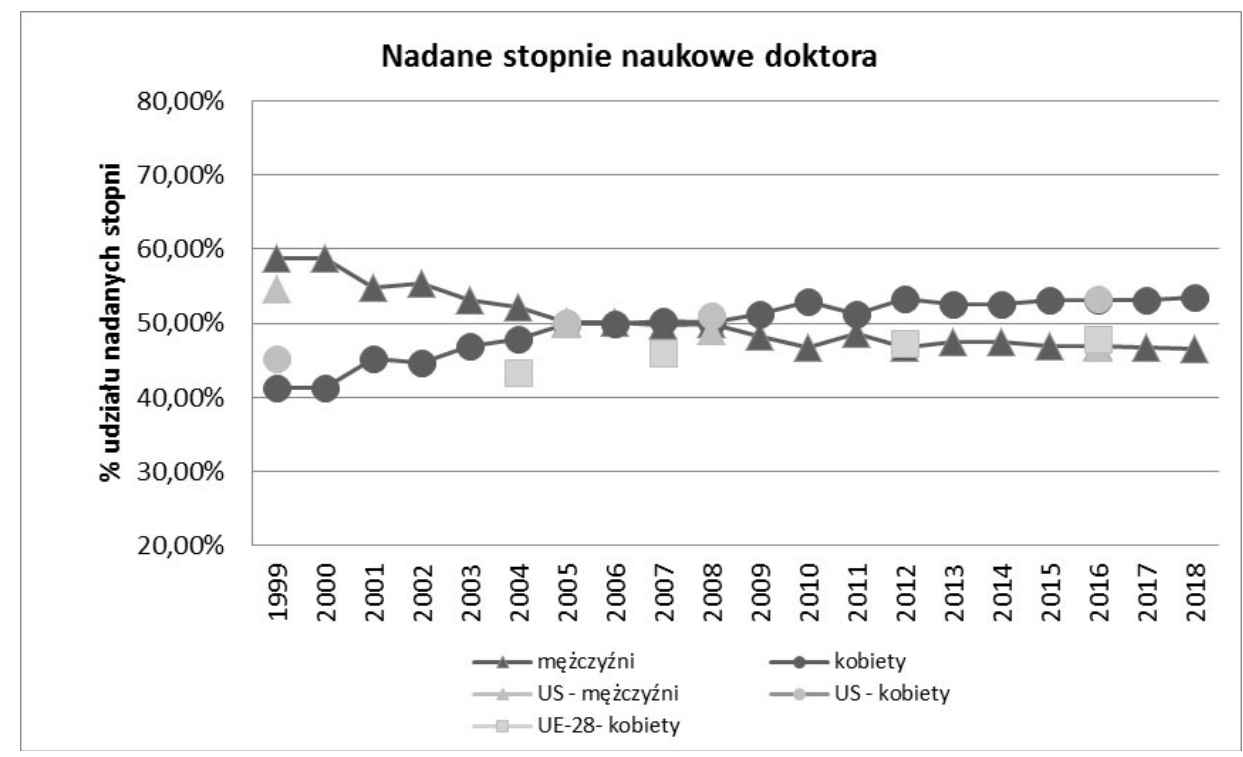

Źródło: opracowanie własne.

Wykres 8. Liczba nadanych w poszczególnych latach stopni doktora

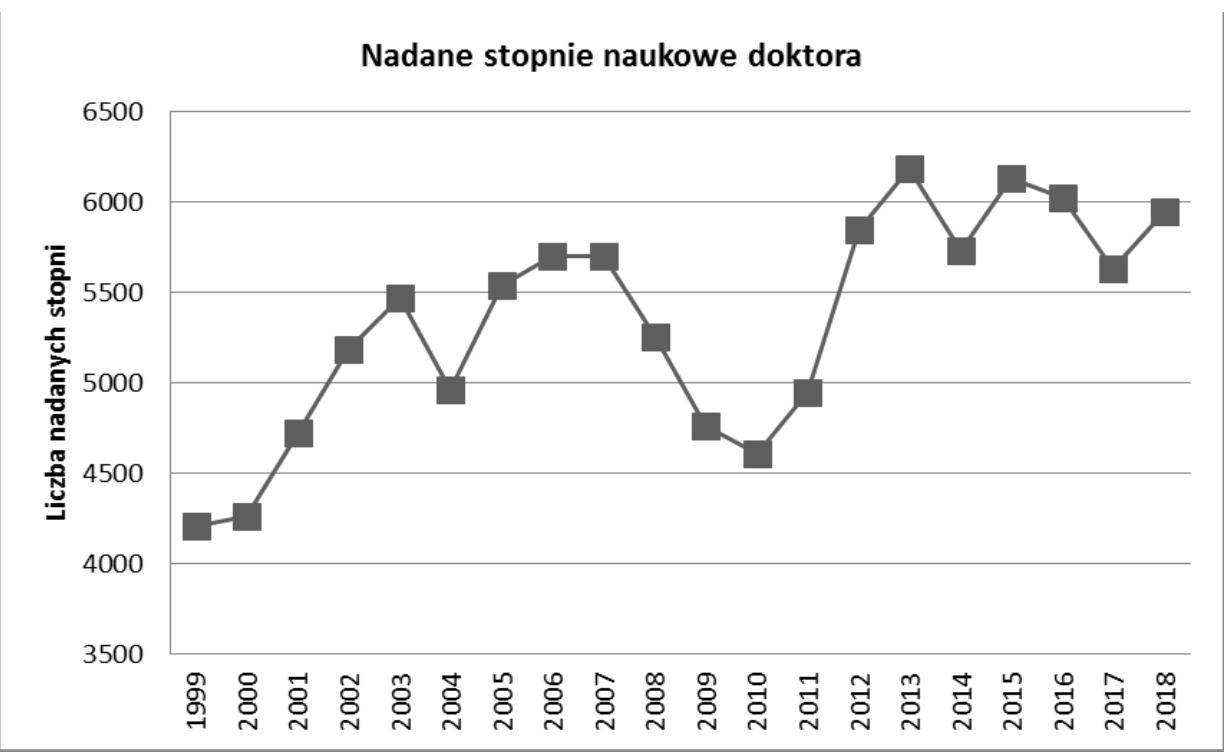

Źródło: opracowanie własne. 
Chociaż w roku 1999 zdecydowanie więcej mężczyzn zdobywało stopień doktora (około 60\%), a zrównanie liczby stopni uzyskiwanych przez kobiety ze stopniami otrzymywanymi przez mężczyzn nastapiło już w roku 2005, to od roku 2012 nie obserwuje się dalszego wzrostu udziału kobiet wśród osób uzyskujących stopień doktora - pozostaje on na poziomie 53\%. Można stąd wnioskować, że jest to poziom „nasycenia” - wszystkie kobiety, które tylko chca, uzyskuja stopień doktora.

Zresztą liczba uzyskiwanych stopni naukowych doktora w ostatnich latach (wykres 8 - od roku 2013) zmniejsza się - podobnie jak liczba nadanych tytułów profesora. W przypadku tytułów nadaje je Prezydent $\mathrm{RP}$, a stopnie nadawane były przez jednostki naukowe posiadajace odpowiednie uprawnienia.

Podsumowanie tych procesów stanowi wykres 9 przedstawiający, jak zmieniał się awans naukowy osób różnej płci w zależności od roku, w którym stopień/tytuł został uzyskany/nadany. Jest to typowy wykres „nożycowy” - jeżeli w analizowanym zakresie ramiona wykresu się nie przecinaja (tak jak w roku 2000) i im sa bardziej odległe (ten sam rok), tym mniejszy awans kobiet w badanym okresie.

Wykres 9. Procentowy udział nadanych w poszczególnych latach tytułów w zależności od obszaru nauk, w których tytuły zostały nadane

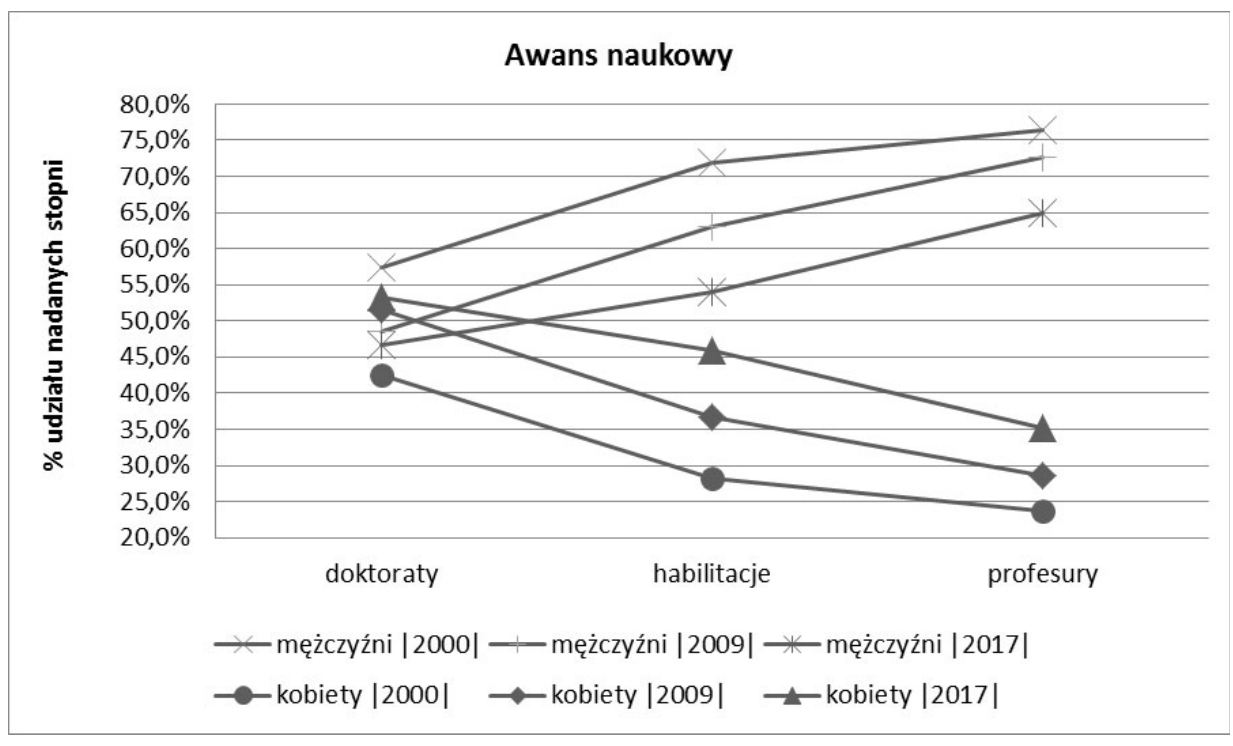

Źródło: opracowanie własne. 
Wartości średnie przedstawione na wykresie zostały uzyskane jako średnia arytmetyczna udziału procentowego dla lat wymienionych w nazwie i lat otaczajacych (czyli dla roku 2000 będzie to średnia arytmetyczna $z$ lat 1999, 2000 i 2001).

Jak można zauważyć, dla wszystkich stopni i tytułów obserwuje się bardzo silny wzrost procentowy stopni uzyskanych przez kobiety i nadanych im tytułów. Najmniejszy wzrost występuje dla stopnia doktora tylko około $10 \%$, a największy dla stopnia doktora habilitowanego - około $17 \%$. Ponadto zmienia się charakter wykresu: po pierwsze pojawia się punkt przecięcia udziału procentowego zdobywanych stopni (czego nie było dla roku 2000), a po drugie zmienia się kształt wykresu ( $z$ wyraźnie wypukłego na wklęsły). Ostatecznie wykres staje się w przybliżeniu liniowy $z$ punktem przecięcia linii (co daje w tym przypadku $50 \%$ kobiet uzyskujacych dany stopień) pomiędzy stopniem doktora i doktora habilitowanego.

Wykres 10. Procentowy udział liczby finansowanych przez NCN projektów ze względu na płeć kierownika projektu

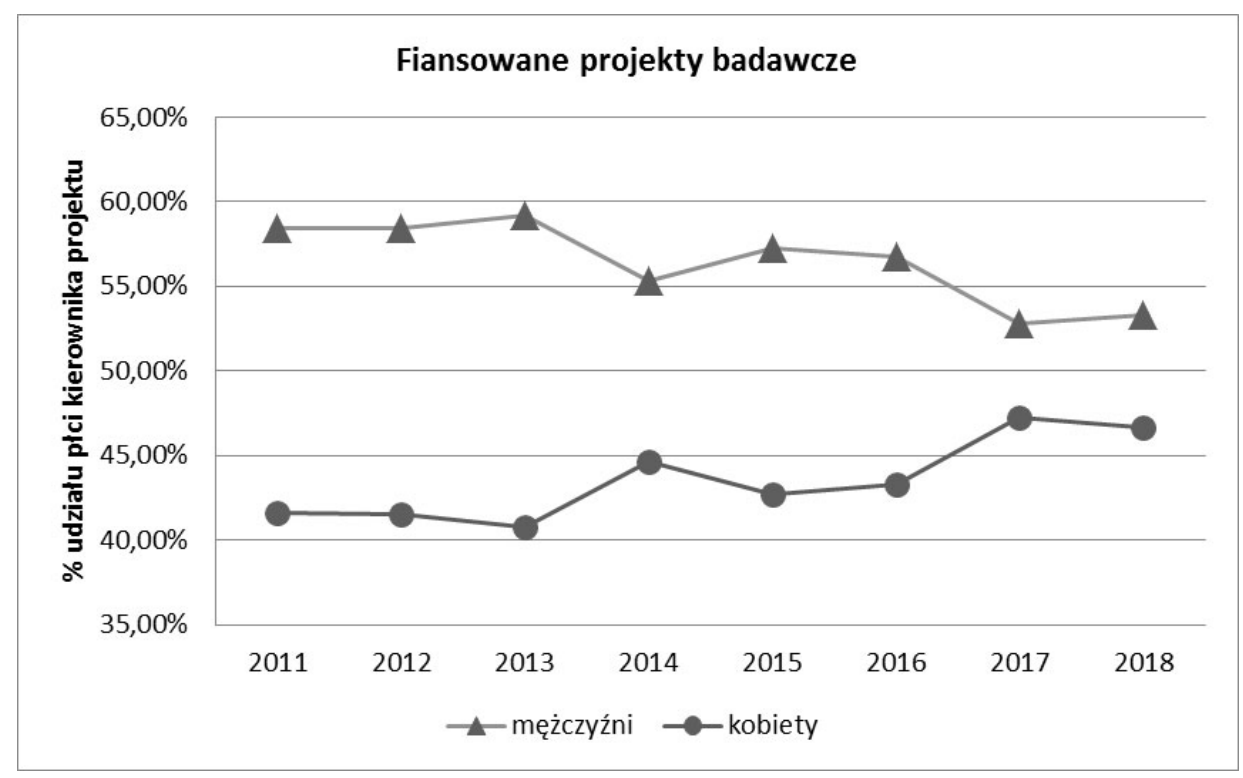

Źródło: opracowanie własne. 
Tendencję do uwzględniania coraz liczniejszego udziału kobiet w nauce obserwuje się również dla projektów finansowanych przez NCN (wykres 10). Ich udział w przyznanych projektach, których kierownikami były kobiety, wzrósł, może nie tak dramatycznie, jak to miało miejsce np. dla habilitacji, ale wyraźnie - o około 5\% (z 43\% do 48\%).

Wykres 11. Wysokość środków finansowych przyznanych przez MNiSW i NCN na realizacje projektów naukowych

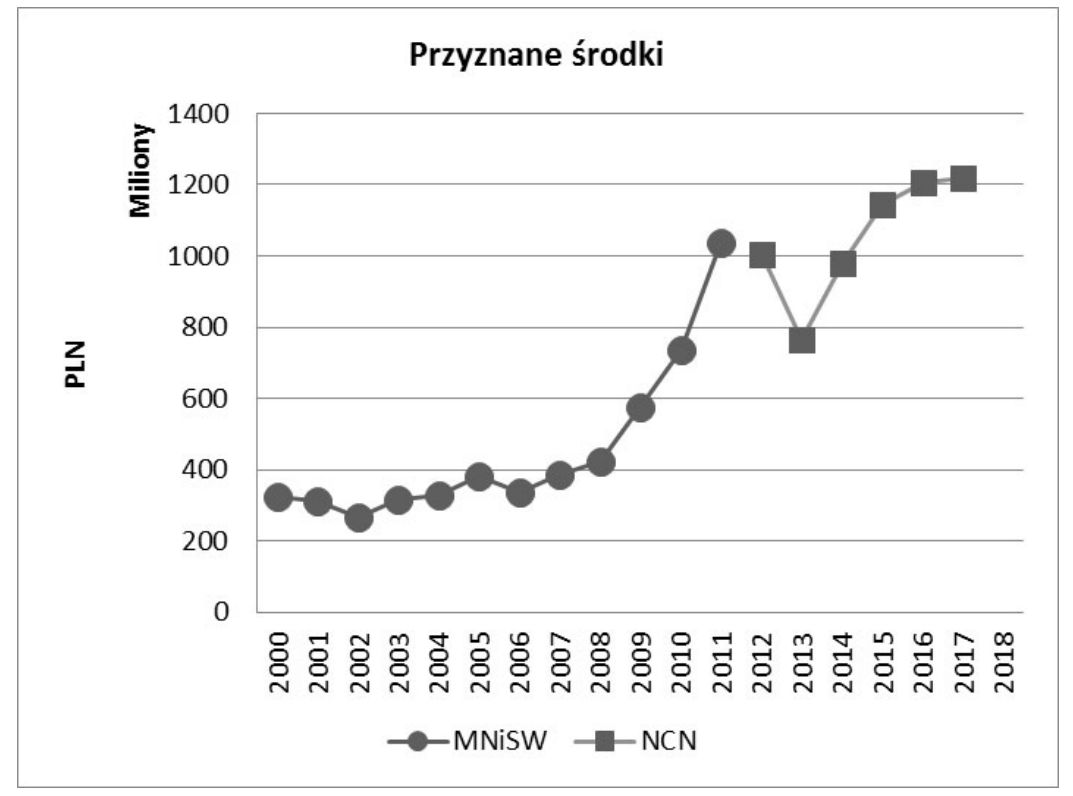

Źródło: opracowanie własne.

Czyli około połowa projektów jest obecnie kierowana przez kobiety. Przy czym przeznaczane na projekty naukowe środki nie sa obecnie mniejsze (wykres 11), ale rosna $z$ roku na rok.

\section{Wnioski}

Analizując przedstawione wyniki, można stwierdzić, że większość $z$ poprzednio przedstawionych trendów nadal (po roku 2015) występuje. Niepokojacy trend do nadawania tytułów osobom starszym (55-64 lat) zanikł - został zastapiony znowu przez tendencję do nadawania tytułów 
naukowych osobom o dekade młodszym (45-54 lat). Martwi bardzo silny spadek liczby nadanych tytułów, jaki nastapił w ostatnich latach (obniżenie w 2017 r. do poziomu najniższego od 20 lat), zwłaszcza że jest on zwiazany ze spadkiem liczby nadawanych stopni naukowych doktora i stabilizacja liczby nadanych stopni doktora habilitowanego.

Zależność awansu naukowego kobiet od roku nadania stopnia/ tytułu również wskazuje na dążenie do coraz większego udziału kobiet w nauce - coraz więcej kobiet uzyskuje stopień naukowy doktora habilitowanego i w związku $z$ tym na wykresie 9 punkt przecięcia się prostych dąży do punktu oznaczającego stopień doktora habilitowanego.

Również, pomimo wzrostu środków przeznaczonych na badania, rośnie odsetek kobiet, które sa kierownikami projektów badawczych, czyli kobiet, które mają decydujący wpływ na rozdysponowanie środków wśród wykonawców projektów.

Można więc bez żadnej przesady, na podstawie tylko danych statystycznych, stwierdzić, że rola kobiet w nauce polskiej umacnia się.

\section{Bibliografia}

\section{Akty prawne}

Rozporzadzenie w sprawie dziedzin nauki i dyscyplin naukowych oraz dyscyplin artystycznych, Dz.U. z 2018 r., poz. 1818.

Rozporządzenie w sprawie obszarów wiedzy, dziedzin nauki i sztuki oraz dyscyplin naukowych i artystycznych, Dz.U. z 2011 r. nr 179, poz. 1065.

Ustawa z dnia 27 lipca 2005 r. Prawo o szkolnictwie wyższym, Dz. U. z 2005 r. nr 164, poz. 1365.

Ustawa z dnia 30 kwietnia 2010 r. o Polskiej Akademii Nauk, Dz. U. z 2010 r. nr 96, poz. 619.

\section{Literatura}

Rodzik, Piotr. „Awans naukowy kobiet - czy coś się zmieniło?”, Nauka, nr 4, 2016, 93-110.

Rodzik, Piotr. „Kto zdobywa stopnie i tytuły naukowe - trochę statystyki”, Sprawy Nauki, nr 4, 2009, 16-20.

Rodzik, Piotr. „Nadane stopnie i tytuły naukowe - czy coś się zmieniło?”, Nauka i Szkolnictwo Wyższe, nr 2 (48), 2016, 139-174. 
"She Figures 2012. Gender Equality in Science", (Brussels : European Commission, 2016).

"She Figures 2015", (Luxembourg : Publications Office of the European Union, 2016).

"She Figures 2018", (Luxembourg : Publications Office of the European Union, 2019).

\section{Źródła internetowe}

Li-Ling Tsai. Yen-Wen Peng. "Statistics of Women in Science and Technology Education: Data from Taiwan, Japan and South Korea" [online] [dostęp: 12.03.2020]. Dostępny w World Wide Web: https://slideplayer.com/ slide/7401984/.

"Number of doctoral degrees earned in the United States from 1949/50 to 2028/29, by gender", Statista, [online] [dostęp: 07.12.2019]. Dostępny w World Wide Web: https://www.statista.com/statistics/185167/number-of-doctoral-degrees-by-gender-since-1950/. 